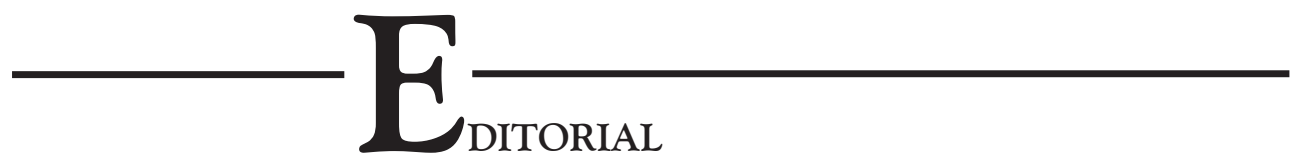

\title{
ATIVISMO POLÍTICO DE GRUPOS RELIGIOSOS E LUTA POR DIREITOS
}

\author{
Lilian Sales \\ Universidade Federal de São Paulo \\ São Paulo - SP - Brasil \\ Orcid: https://orcid.org/0000-0002-4169-1149 \\ Ricardo Mariano \\ Universidade de São Paulo \\ São Paulo - SP - Brasil \\ Orcid: https://orcid.org/0000-0002-8916-1542
}

Os artigos do dossiê "Religião e luta por direitos" presentes neste volume de Religião $\mathcal{E}$ Sociedade examinam a participação de organizações e lideranças religiosas hegemônicas no Brasil, sobretudo cristãs, em disputas e controvérsias políticas por direitos. Revelam que seus agentes atuam em diferentes trincheiras e frontes, inclusive uns contra os outros, seja defendendo o direito à liberdade religiosa, os direitos sociais e o Estado de direito, seja se opondo a eles e a demandas por direitos sexuais e reprodutivos e aos Direitos Humanos de minorias, seja disputando a definição e interpretação jurídico-política do princípio da laicidade constitucional e sua aplicação nas diretrizes governamentais, nas políticas públicas, nos legislativos, na escola pública, e daí por diante. 
A abrangência e os objetivos do ativismo político comandado por atores religiosos extrapolam, e muito, os espaços e instituições da sociedade civil, lócus convencional de atuação política católica desde a formação da Ação Católica nos anos 1930.É notório o avanço acelerado da ocupação religiosa de concessões públicas de rádio e TV e das instituições políticas. Ela ocorre por meio do engajamento eleitoral de pastores, bispos, apóstolos, padres, da criação de partidos políticos por igrejas (PRB), da participação em julgamentos do poder judiciário, da formação de bancadas parlamentares evangélica e católica, da eleição de candidatos ao executivo que instrumentalizam politicamente sua identidade religiosa e os lemas "maioria cristã", "Deus acima de tudo", entre outros. Parte desses ativistas não esconde o propósito de inserir crenças e valores religiosos na normatividade jurídica, nas políticas públicas, nas escolas. Seu ativismo impacta não só os legislativos, mas também o poder executivo, seja em sua composição política, seja em suas políticas públicas. Vide, por exemplo, o Ministério da Mulher, da Família e dos Direitos Humanos, sob o comando da pastora Damares Alves. Comecemos pelo ativismo católico.

\section{Ativismo católico e direitos no Brasil}

Se a atuação e intervenção política dos evangélicos em questões de interesse público se destaca na atualidade, a Igreja Católica mantém-se politicamente ativa desde o descobrimento, resultante da união entre "espada e cruz". O regime de padroado assegurou sua aliança (subalterna) com o Estado brasileiro por quatro séculos. Mesmo por ocasião de sua indesejada separação do Estado com o advento da República, exerceu importante papel na definição do regime de relações entre Estado e religião (Giumbelli 2008). Na Primeira República, ampliou consideravelmente seu poder político em meio ao projeto de neocristandade capitaneado por D. Sebastião Leme, além de manter a ocupação de "espaços consideráveis nas áreas da saúde, educação, lazer e cultura” (Miceli 1988:28).

A atuação católica em assuntos de interesse público perdurou por todo o século, assim como sua presença e influência na sociedade civil, tomada, inclusive, como modelo e referência para a formulação de direitos (Montero 2006). Contudo, na segunda metade do século, afastou-se paulatinamente da política institucional, priorizando o engajamento na política societária, que prossegue sua principal forma de atuação política, apesar da recente inserção de grupos católicos, sobretudo carismáticos, na política institucional, seguindo, até certo ponto, o modelo corporativo do ativismo político evangélico.

$\mathrm{Na}$ contramão da privatização do religioso apregoada pelas ideologias liberal e republicana e prevista pela teoria da secularização, grupos evangélicos e católicos vêm ampliando seu ativismo nas eleições, nos partidos, nos legislativos, nos governos, nas políticas públicas, em disputas públicas e judiciais em torno de direitos. Diferentemente do que se preconizava e se esperava, não se observa o declínio acentuado da 
participação religiosa da população - com exceção, em especial, da Europa ocidental e de estados norte-americanos mais ricos, como Califórnia e Nova Iorque - e muito menos o confinamento da religião à vida privada. Países europeus altamente secularizados não estão imunes aos acirrados debates públicos sobre o lugar, o papel e as fronteiras do religioso, tampouco em relação às demandas por direitos sexuais e reprodutivos. Na França, por exemplo, as controvérsias sobre a legalização do "matrimônio gay" e da adoção de crianças por casais homossexuais, o uso do véu, a discriminação de minorias religiosas, sobretudo islâmicas, e as crescentes reivindicações de grupos religiosos por maior espaço, visibilidade e poder na esfera pública têm colocado em crise a laïcité, arranjo jurídico-político francês de regulação estatal da religião.

Como observam pesquisadores da religião, nas últimas duas décadas, o lobby e a participação direta de atores religiosos em instituições políticas, movimentos sociais, manifestações de protesto, controvérsias públicas, disputas judiciais e mídias tornaram-se cada vez mais frequentes no Brasil, noutros países da América Latina e de outros continentes (como Turquia, Índia, entre outros).

Esse dossiê não tenciona analisar as relações entre atores religiosos e instituições políticas, jurídicas e estatais a partir de perspectivas que ora preconizam ideologicamente, ora preveem teoricamente a privatização do religioso. Antes, procura observar, no plano empírico, suas formas de intersecção e sobreposição, ou o fato de que as fronteiras entre religião, política e Estado se mostram, frequentemente, porosas e borradas, em vez de rígidas e impermeáveis. Não se procura, portanto, identificar ou demarcar fronteiras ou esferas, nem como ponto de partida conceitual e nem como ponto de chegada analítico-descritivo. Importa, sobretudo, analisar o ativismo sociopolítico de atores religiosos e o de seus adversários em luta contra e a favor de direitos em diversos ambientes seculares, tais como os parlamentos, as eleições, o judiciário, os movimentos sociais, o espaço público (marchas, jornadas), as redes sociais, as mídias.

Os engajamentos de atores religiosos, individuais ou coletivos, envolvidos na luta por direitos nesses ambientes seculares, cabe frisar, costumam reverberar, acima de tudo, moralidade, interesses, valores e posições de suas organizações religiosas. Nem por isso apresentam uniformidade de ação e propósito, dadas a diversidade interna e suas diferenças e divergências políticas, partidárias e institucionais. Isso ocorre não obstante a hegemonia religiosa e política dos grupos cristãos conservadores.

Apesar da sua disposição religiosa, tendem a convergir, cada vez mais, na estratégia de acionar repertório e gramática dos direitos, das ciências, da ecologia, etc., adotando fontes normativas seculares para defender suas convicções religiosas e suas pautas políticas. Com isso, visam legitimar politicamente suas posições, seus argumentos e seus procedimentos em debates públicos, disputas políticas e judiciais. Convergem no acionamento deum secularismo estratégico, conforme expressão de Vaggione (2017), estratégia identificada em vários artigos deste dossiê. Demonstram, assim, reconhecer a legitimidade e autoridade inescapável do arcabouço constitucional e 
das instituições políticas e estatais, bem como a necessidade de fazer uso prioritário de repertório secular e da gramática dos direitos nos litígios de que participam na arena pública.

Como se observou, é antiga a participação de representantes da Igreja Católica e de suas instituições em questões de interesse público no Brasil. Em boa parte do século XX, a Igreja Católica ocupou posição-chave como agência reguladora da vida social, fomentadora de formas de mobilização social e da construção de uma cultura cívica e de uma moralidade pública. Durante a ditadura militar, exerceu destacado papel político na constituição e defesa de uma "cultura dos direitos", sobressaindo-se nas lutas em prol da restauração dos direitos civis e políticos e da promoção dos Direitos Humanos e da democracia (Rosado-Nunes 2008); papel que protagonizou também em reação à perseguição, à tortura, à prisão, à morte e ao exílio de frades, freiras e padres. Nas dioceses, formaram Centros de Defesa de Direitos Humanos e Comissões de Justiça e Paz, instituições que atuaram na mídia, na política e na área jurídica para denunciar as violações dos Direitos Humanos, defender as vítimas do regime militar, proteger os presos políticos, em suma, vocalizar publicamente a defesa intransigente dos direitos e das liberdades individuais(Mainwaring 1989; Steil e Toniol 2012) ${ }^{1}$.

A partir da redemocratização, a ação eclesial em prol dos direitos de cidadania intensificou-se, especialmente pela promoção dos Direitos Humanos enquanto direitos sociais, reforçando o ativismo em defesa de sua incorporação na legislação ${ }^{2}$. Para tanto, a cúpula católica, agentes pastorais e seus aliados militaram pela realização da Constituinte e participaram de seus trabalhos em subcomissões, frequentemente como expositores externos. Defenderam a proibição do aborto, da tortura e da eutanásia, a oferta de ensino religioso nas escolas públicas, a dotação de recursos a escolas não estatais sem fins lucrativos, a primazia do trabalho sobre o capital e a reforma agrária baseada na função social da propriedade privada. Aliados da Pastoral do Menor destacaram-se pela elaboração e aprovação do Estatuto da Criança e do Adolescente (Wohnrath 2017).

Nesse período, a Conferência Nacional dos Bispos do Brasil (CNBB) incorporou e difundiu a noção de direitos nos discursos e proposições de ação pastoral, investindo na circulação de concepções de cidadania entre sacerdotes e movimentos leigos. Naquele contexto, as Campanhas da Fraternidade, organizadas pela CNBB, abordaram, em sua maioria, temas defendendo a promoção e expansão dos Direitos Humanos, como o direito à saúde e à moradia, os direitos de crianças e adolescentes. Isso demonstra a centralidade que a cúpula eclesiástica atribuía aos direitos e sua prioridade em promovê-los junto à população ${ }^{3}$, haja vista que as Campanhas da Fraternidade, lançadas anualmente, se compõem de pregações, de mensagens e passagens bíblicas, de imagens e hinos sobre o tema escolhido, que são reproduzidos, sistematicamente, em rituais e missas nas paróquias por todo o ano litúrgico. A estrutura centralizada da Igreja e a capilaridade do catolicismo contribuíram para defender os Direitos Humanos e socializá-los em parte da população4. 
O ativismo católico em defesa dos Direitos Humanos tem seu ponto de inflexão diante dos direitos sexuais e reprodutivos. A Igreja opõe-se à expansão desses direitos e "bate de frente" com os movimentos feministas e LGBTs que os reivindicam. Vide a proposta da CNBB de inserir a frase "defesa da vida desde a concepção" no texto constitucional, visando impedir a realização do aborto em qualquer situação (Dalmolin 2011; Rocha 2005), o que representaria um retrocesso mesmo em relação à legislação anterior, que previa o aborto legal apenas nos casos de estupro e de risco de vida da mãe. Posteriormente, entidades pastorais e CNBB reforçaram seu ativismo nessa área, aliando-se a ativistas, movimentos e redes internacionais antiaborto em defesa da "vida desde a concepção" (Rezende 2016).

Diante disso, a legislação do aborto só seria modificada, timidamente, em 2012, quando, no julgamento da ADPF 54, o Supremo Tribunal Federal (STF), enfrentando forte resistência católica, descriminalizou a interrupção da gestação de fetos anencéfalos. Anos antes, em 2008, a CNBB opôs-se à liberação do uso de células embrionárias em pesquisas científicas, aprovada pelo STF no julgamento da ADI 3.510. Em ambas as ocasiões, defendeu suas posições em audiências públicas no STF e em sua rede midiática e mediante a divulgação de reportagens, documentários e testemunhos (Sales 2014, 2015; Luna 2013, 2018).

Em diversas disputas judiciais, atores católicos, a partir dos anos 2000, lançaram mão de novas estratégias de ação contra o aborto, a reprodução assistida e a eutanásia. Duas se destacam: 1) passaram a apoiar-se em repertório e modus operandi acadêmicocientífico e na gramática dos direitos para defender suas convicções; 2) vincularam-se a movimentos antiaborto que se intitulam laicos. Com isso, nos litígios públicos sobre o aborto, seus ativistas deixaram de mencionar e operar com termos, referências e crenças convencionalmente compreendidos como católicos, como dogmas de fé, personagens sagrados, passagens bíblicas ou de textos confessionais. Em vez disso, priorizaram a adoção de justificativas e argumentos em defesa da "vida" baseados em interpretações e citações científicas e jurídicas. Incorporaram, assim, o modus operandi acadêmicocientífico no plano discursivo, mas também na seleção de seus representantes e intérpretes para pugnar nas disputas públicas, entre os quais juristas, médicos, biomédicos, que, em geral, imputam "vida humana" aos fetos e os caracterizam como indivíduos e sujeitos plenos de direito (Montero, Silva e Sales 2018; Luna 2018).

Nas últimas décadas, o ativismo cristão contra os direitos sexuais e reprodutivos e as demandas por igualdade de gênero alcançaram escala mundial. As campanhas antigênero e antidireitos com base na categoria acusatória "ideologia de gênero" globalizaram-se, segundo Corrêa, Paternotte e Kuhar (2018). Nos Estados Unidos e em países europeus, dotados de legislação mais liberal em questões de gênero, sexualidade e direitos reprodutivos, grupos cristãos conservadores têm se mobilizado intensamente para tentar embaraçá-los e até revertê-los e impedir a legalização dos novos pleitos de feministas e LGBTs. Apelam para a defesa de concepções tradicionais de família e de relações de gênero para defender a "vida" e se opor a direitos, escolhas e 
tecnologias envoltos em debates bioéticos (de ordem moral, médica, filosófica, etc.) relativos a aborto, fertilização in vitro, clonagem, eutanásia, uso de células embrionárias em pesquisas.

Na América Latina, o avanço dos direitos sexuais e reprodutivos é recente e, de modo geral, limitado. Grupos e movimentos cristãos conservadores lideram as ações (inclusive, preventivas) contra a legalização e efetivação dos direitos demandados por mulheres e LGBTs e a regulamentação bioética. No Brasil, as bancadas parlamentares evangélica e católica unem forças contra seus adversários.

A atuação de movimentos vinculados à Igreja Católica em controvérsias públicas sobre o início e o fim da vida e os direitos sexuais e reprodutivos (aborto, casamento homossexual, união civil homoafetiva) foi classificada por pesquisadores do catolicismo na Europa como "ativismo católico" (Portier e Béraud 2015; Turina 2012; Vaggioni 2017) ou "militantismo católico" (Garbagnoli e Prearo 2017). Para Isacco Turina (2012), esses temas compõem novo campo de enfrentamento entre estados nacionais europeus e latino-americanos e a Igreja Católica. Não faltam exemplos: conferências episcopais e movimentos católicos laicos opuseram-se ao casamento homossexual, à união civil homoafetiva e à inserção da educação sexual nos manuais escolares na França; à reprodução assistida e ao casamento homossexual na Itália; à regulamentação do aborto na Espanha; à eutanásia na Bélgica e na Argentina (Portier 2012; Vagionni 2017; Dobbelaere e Perez-Agote 2015;Béraud 2013; Turina 2012).

Esse ativismo católico nada tem de aleatório. Resultou, inicialmente, de uma ofensiva orquestrada pelo Vaticano, que remonta aos anos 1960 (em reação à revolução sexual, ao uso da pílula anticoncepcional, etc.), com a Encíclica Humanae Vitae, de 1968, que estabeleceu a centralidade da "vida" e de sua reprodução e proibiu o aborto e a contracepção por meios artificiais. No pontificado de João Paulo II, a reprodução da vida, a sexualidade e a complementaridade entre os sexos ganharam destaque, tornando-se objetos recorrentes de textos oficiais (Carnac 2013).

No Vaticano, esses temas adquiriram sentido de urgência a partir de meados dos anos 1990, em reação às vitórias do movimento de mulheres nas Conferências da ONU no Cairo (1994) e em Pequim (1995), quando, em aliança com grupos neomalthusianos, conquistaram o reconhecimento dos direitos sexuais e reprodutivos como Direitos Humanos. Após fracassar em impedir tal reconhecimento, o Vaticano envidou esforços para criar expertise, formular e difundir sua produção doutrinária antigênero e avessa aos direitos sexuais e reprodutivos, a fim de preparar-se para o enfrentamento de disputas políticas sobre tais temas nos países de tradição católica, bem como em fóruns e organizações internacionais. Desde então, a hierarquia católica recrudesceu o investimento, em nível global, no ativismo contrário às questões de gênero, de bioética e de reprodução humana. Principiou sua ofensiva após a Conferência do Cairo (1994), com a publicação de textos doutrinais, inclusive de encíclicas e da "Carta às mulheres", da lavra de João Paulo II. Intensificou o ativismo após a Conferência Internacional da Mulher em Pequim (1995), com a publicação no 
mesmo ano da Encíclica Evangeliun Vitae, na qual se posicionou sobre reprodução e bioética e cunhou a categoria "cultura de morte" para opor-se a toda interrupção não "natural" da vida humana, como aborto e eutanásia (Oliveira 2018).

A reação católica ocorreu, primeiramente, no campo teológico, com a produção de encíclicas e de outros documentos doutrinais sobre as novas tecnologias reprodutivas, a bioética, o aborto, a eutanásia, o casamento homossexual. De pronto, difundiu seu conteúdo moral e doutrinal junto a seu corpo institucional e a suas bases laicas. Em seguida, fez-se acompanhar de uma ofensiva acadêmico-científica, com a criação de institutos para alocar e formar um corpo de experts, visando conferir ares de cientificidade a seus posicionamentos doutrinários ${ }^{6}$. Assim, em 2005, o Pontifício Conselho para a Família (2003) publicou o Lexicon: termos ambíguos e discutidos sobre família, vida e questões éticas, na forma de um dicionário enciclopédico, traduzido e lançado em nove línguas (Béraud 2013). A obra levou uma década para ser elaborada por teólogos em conjunto com acadêmicos, cientistas e juristas, que estudaram, sistematizaram e redigiram a doutrina católica sobre bioética, gênero e sexualidade. No Léxico, os argumentos "em defesa da vida" e "antigênero" articularam-se e revestiram-se de um "discurso secular, científico e feminista, que reforça a concepção da complementaridade entre os sexos" (Garbagnoli e Prearo 2017:58). Visam, sobretudo, desacreditar os estudos de gênero, além de fundamentar e promover cruzadas contra comportamentos e reivindicações que neles se apoiam ou que destoam da moralidade cristã tradicional (Garbagnoli 2014).

\section{Ativismo político evangélico em confronto com os Direitos Humanos}

Por ocasião da Constituinte, Flávio Pierucci (1996) destacou o pedigree majoritariamente conservador e o pendor fundamentalista da bancada evangélica, rotulou-a de "direita cristã" e ressaltou o apelo popular de suas demandas moralistas e tradicionalistas por "lei e ordem", "moralidade e decência". Enfatizou sua "preocupação de fundo" "com o sexo, com a moral sexual" (Pierucci 1996:178), o que, aliás, remete à obsessão evangélica atual com a proteção da família, tida sob ataque de forças demoníacas e comunistas. Aliados do Centrão na Constituinte, deputados evangélicos identificaram-se como conservadores e opuseram-se à proibição da discriminação por orientação sexual, liderando manifestação de centenas de pessoas contra o aborto, a pornografia e os homossexuais na Câmara dos Deputados. Não à toa, Pierucci sublinhou seu parentesco com a New Christian Right norte-americana.

De lá para cá, na esteira de sua expansão demográfica liderada pelos pentecostais, esses religiosos ampliaram consideravelmente seu ativismo político, sua base parlamentar e sua estrutura midiática. Em aliança com grupos e parlamentares católicos carismáticos, a Opus Dei, movimentos "pró-vida" e "pró-família" passaram a protagonizar o ativismo político cristão conservador no Brasil (Machado 2017). Para tanto, no Congresso Nacional, a bancada evangélica, composta por noventa deputados e nove senadores na atual legislatura, conta com apoio e assessoria do Fórum 
Evangélico Nacional de Ação Social e Política (FENASP), da Associação Nacional de Juristas Evangélicos (ANAJURE), do Movimento Brasil sem Aborto, entre outros (Vital da Cunha e Lopes 2013:158).

Em contraste, os grupos evangélicos ditos progressistas são minoritários e pouco visíveis e não dispõem, praticamente, de representação parlamentar e da posse de meios de comunicação de massa. Ademais, volta e meia, enfrentam a desconfiança de grupos, movimentos e partidos de esquerda. Apesar disso, ampliaram sua participação política nos últimos anos. Como, em geral, não dispõem de apoio denominacional, priorizam a formação de coletivos e redes feministas, antirracistas, de defesa dos direitos humanos, da cidadania e da democracia e de candidatos. Embora atuem prioritariamente nas redes sociais, em especial no Facebook, realizam cultos, vigílias, encontros, seminários, workshops, atos públicos, publicam livros, manifestos, notas e denúncias públicas (Vital da Cunha, Lopes e Lui 2017). São diversos os grupos evangélicos progressistas, entre eles: Frente Evangélica pelo Estado de Direito, Movimento Negro Evangélico, Evangélicxs pela Diversidade, (fé)ministas, Evangélicas pela Igualdade de Gênero, DJR - Discipulado, Justiça e Reconciliação, Cristãos contra o fascismo, Rede FALE, Rede Evangélica Nacional de Ação Social (RENAS).

O notório pedigree conservador do segmento evangélico brasileiro deriva, em boa medida, da influência exercida, por distintos meios, sobre o pentecostalismo e outras correntes protestantes pelo evangelicalismo norte-americano, reconhecido por seu conservadorismo teológico, moral e político. Nos Estados Unidos, sua matriz político-religiosa radica-se em grupos protestantes brancos, que comandam, há um século, uma tradição cristã antipluralista. Segundo o historiador Allan Lichtman (2008), essa vertente prioriza a defesa dos valores cristãos tradicionais e da família, concentrando-se na proteção da autoridade masculina, na contenção da sexualidade e dos direitos das mulheres, no combate ao aborto, à homossexualidade, à educação sexual nas escolas, ao darwinismo e às reivindicações feministas, acusando-as de corroer o patriarcado, masculinizar as mulheres e afeminar os homens (Lichtman 2008). As ênfases antipluralista, patriarcalista, antifeminista, familista e criacionista são reforçadas pela velha condenação fundamentalista da crítica histórica e literária da Bíblia, da pregação do evangelho social, do humanismo secular e do secularismo.

Esse substrato ideológico conservador constitui, grosso modo, o núcleo moral e teológico predominante do movimento evangélico, inclusive no Brasil. E tem implicações políticas, pois contrapõe frontalmente seus líderes pastorais e parlamentares a proposições dos Direitos Humanos reivindicadas por feministas e LGBTs, entre outros, e defendidas por partidos e movimentos de esquerda. Tanto que combatem, majoritariamente, a criminalização da homofobia e os programas que visam debelá -la, as políticas públicas de promoção da igualdade de gênero, a união de pessoas de mesmo sexo, a educação sexual nas escolas e a descriminalização do aborto. Julgam que tais proposições e direitos desrespeitam suas crenças, afrontam os valores cristãos, ameaçam sua liberdade religiosa, incentivam a dissolução da família e atentam 
contra os desígnios divinos. Sua disposição em combatê-los (e aos que os defendem) recrudesce à medida mesma que politizam e instrumentalizam eleitoralmente sua identidade religiosa, concebem sua religião, sua moralidade e suas doutrinas como fonte de autoridade política e se consideram representantes de Deus e de igrejas no exercício de suas funções públicas e parlamentares. Resulta disso a instrumentalização religiosa da atividade política para promover interesses institucionais das igrejas, proteger a família tradicional, a "maioria cristã", as "verdades bíblicas", etc.

No início da legislatura anterior (2015-2018), a ligeira expansão da bancada evangélica na Câmara Federal foi associada à irrupção de uma "onda conservadora" na política brasileira e, em especial, no Congresso Nacional. Ela integraria o núcleo mais retrógrado dessa onda, a chamada bancada "BBB": "bala, boi e Bíblia". Martelada pela imprensa, tal associação nada teve de gratuita; escudou-se na aproximação política entre esses grupos conservadores, mas também na ferrenha oposição evangélica aos Direitos Humanos e minorias, que caracteriza sua atuação política desde a Constituinte.

À medida que prosperaram os movimentos LGBT, suas demandas por direitos e sua articulação e representação política, especialmente por meio da formação da Frente Parlamentar Mista pela Livre Expressão Sexual, em 2003, parlamentares evangélicos engajaram-se cada vez mais em controvérsias públicas em torno de temas e políticas inclusos no rol de programas e tratados de Direitos Humanos. Geralmente, como seus oponentes. Basta observar sua oposição aos programas federais de combate à homofobia a partir de 2004; seu repúdio ao PLC 122/2006, que propunha criminalizá-la; sua rejeição, em 2010, ao III Programa Nacional de Direitos Humanos, que propunha a descriminalização do aborto; sua mobilização, em 2011, para vetar a distribuição, pelo Ministério da Educação, do Caderno Escola sem Homofobia aos alunos dos ensinos fundamental e médio, material didático que tinha por objetivo combater a "discriminação por orientação sexual", o qual rotularam de "kit gay" e trataram como artimanha esquerdista e diabólica para homossexualizar crianças, destruir famílias e fazer "apologia ao homossexualismo e à promiscuidade".

Em 2013, envolveram-se em nova escalada de conflitos em torno dos Direitos Humanos com a ocupação da presidência da Comissão de Direitos Humanos e Minorias (CDHM), da Câmara dos Deputados, pelo pastor Marco Feliciano (PSC/SP). Acusado de racista, homofóbico, intolerante e fundamentalista e alvo de inúmeras manifestações de protesto e da oposição parlamentar de esquerda, Feliciano assumiu a CDHM afirmando que iria defender os "verdadeiros direitos humanos" e dar "atenção às verdadeiras minorias" numa comissão que, a seu ver, até então fora dominada pelo diabo (leia-se PT) (Gonçalves 2016).

Com a CDHM tomada por evangélicos, Feliciano priorizou a tramitação e aprovação de proposições de seus pares cristãos, com destaque para o PL 234/2011, proposto pelo pastor assembleiano João Campos (PSDB/GO) e rotulado de "cura gay" por seus detratores. De imediato, recusou aos LGBTs a condição de minoria discriminada, argumentando que "os gays" "são estudados e têm ótimos empregos". 
Acusou-os de não reivindicarem direitos iguais, mas, sim, privilégios em prejuízo da maioria cristã, reiterando denúncias desferidas por seus aliados. Entre elas, a do autor do Estatuto da Família, que, invertendo a ordem factual da vitimização, alegou que os cristãos precisam defender os direitos da maioria heterossexual, que, a seu ver, seria vítima da opressão do movimento LGBT? .

Em discurso no plenário da Câmara Federal em 16 de dezembro de 2013, Feliciano fez um balanço de sua atividade como presidente da CDHM, asseverando sua "luta em favor da família bíblica tradicional, composta de pai, mãe e filhos", e da "vida desde a concepção". Conclamou a união dos cristãos para atuar em prol desses ideais religiosos contra forças e inimigos ocultos, ardilosos, "tal qual a serpente" bíblica, que pretendem "impor seus valores" e "começar a educação das crianças cada vez mais cedo, substituindo os pais na educação básica, impondo valores alienígenas já na primeira infância, com a clara intenção de criar uma geração de pessoas versáteis para a sexualidade, onde entra a palavra gênero".

A CDHM, sob comando pastoral, serviu de palco inicial para a luta cristã antigênero, isto é, para o combate ao que nomeiam "ideologia de gênero". Mas foi na área de educação que a bancada evangélica protagonizou a peleja antigênero. Em 2014, vetou a inclusão da promoção da igualdade de gênero e de orientação sexual no Plano Nacional da Educação, em meio a acirrados debates na Câmara dos Deputados. Em seguida, desatou a propor projetos de lei nos legislativos federal, estadual e municipal para implantar o Escola sem Partido contra a suposta "doutrinação ideológica" marxista, comunista e de gênero nas escolas (Miguel 2016).

Em 2015, fazendo jus à inclusão da bancada evangélica no miolo da "onda conservadora", o assembleiano Eduardo Cunha (PMDB/RJ), após assumir a presidência da Câmara Federal, desarquivou e acelerou a tramitação de projetos de lei de seus irmãos de fé, que turbinaram a produção legislativa avessa aos Direitos $\mathrm{Hu}$ manos e à igualdade de gênero. Lançaram o "Estatuto do Nascituro" (PL 478/2007; coassinado por deputados católico e evangélico), que proíbe o aborto em todos os casos, inclusive nos três previstos em lei; e o "Estatuto da Família" (PL 6583/2013), que restringe o conceito de família à união entre homem e mulher, proíbe a adoção de crianças por casais homoafetivos, pleiteia a criação do Dia Nacional de Valorização da Família, propõe que escolas públicas e privadas realizem atividades sobre a "importância da família no meio social" e torna obrigatória a inclusão da disciplina "Educação para a família" nos currículos escolares. Cunha desarquivou também os PLs 7180 e 7181, de Erivelton Santana (Patri/BA), pastor da Assembleia de Deus, que, em meio a outros projetos, encabeçam o programa Escola sem Partido para assegurar, na Lei de Diretrizes e Bases e nos parâmetros curriculares nacionais, que "os valores de ordem familiar" tenham "precedência sobre a educação escolar nos aspectos relacionados à educação moral, sexual e religiosa". Ele ainda avalizou a criação da Comissão Parlamentar Especial "Escola sem Partido", controlada por pastores e apoiada pela bancada católica. Desde então, transformaram a educação pública, as 
escolas e universidades, a atividade docente e o material didático em verdadeiros campos de batalha. Sob o atual governo, teorias conspiratórias do Escola sem Partido capturaram o imaginário e diretrizes do Ministério da Educação.

Os conflitos políticos em torno dos direitos LGBTs e de demandas feministas foram fundamentais para a radicalização do antipetismo entre lideranças denominacionais e na bancada evangélica. A conflituosa relação entre Eduardo Cunha (PMDB/RJ), PT e Governo Dilma estimulou o peemedebista, então sob escrutínio de investigações policiais e judiciais da Lava-Jato, a abrir o processo de impeachment contra a petista. Naquele momento, diligências e acusações da Lava-Jato sobre dirigentes, governantes e aliados do PT, incluindo a cúpula do PMDB, ocorreram aos borbotões e foram reproduzidas sem filtro por órgãos de imprensa. Tais denúncias ecoaram intensamente nos protestos de multidões nas ruas contra o governo federal. Não obstante esse cenário fosse de todo desfavorável a Dilma, a seu governo e a seu partido e reduzisse sua capacidade de reação e articulação política, ele não explica sozinho a crescente oposição evangélica ao PT. Os conflitos entre petistas e parlamentares evangélicos envolvendo questões de gênero, Direitos Humanos, direitos sexuais e reprodutivos, acirrados a partir de 2011, foram decisivos para que, em maio de 2016, dentre as bancadas do Congresso Nacional, a evangélica se destacasse como a que mais votou a favor do impeachment (89\%).Vários desses parlamentares, não à toa, enfatizaram que votaram pelo impeachment em nome de Deus e da família. A declaração de voto de Feliciano a favor do impeachment amalgama, numa frase, a articulação evangélica com grupos e ideólogos de direita, a referência a Deus, à família e aos evangélicos, o apelo ao povo e a demonização dos adversários: "Com ajuda de Deus, pela minha família e pelo povo brasileiro, pelos evangélicos da nação toda, pelos meninos do MBL, pelo Vem pra Rua, dizendo que Olavo tem razão, dizendo tchau para essa querida, e dizendo tchau ao PT, partido das trevas, eu voto sim!".

Em 2011, principiou a oposição evangélica ao governo Dilma, cuja primeira candidatura à presidência, em 2010, já havia enfrentado tipos diversos de acusações, boatos conspiratórios e persecutórios disseminados em igrejas e redes sociais religiosas e, estrategicamente, insuflados pela campanha tucana. Tal oposição recrudesceu em 2013, como vimos, em razão dos agudos conflitos entre petistas e deputados evangélicos em luta pelo domínio da CDHM e das políticas dos Direitos Humanos. E radicalizou-se a partir de 2016, quando apoiaram o impeachment e ingressaram no Governo Temer.

Em 2018, optaram majoritariamente pela candidatura do capitão da reserva, que passara oito anos escudando a bancada evangélica contra governos e políticas públicas petistas, combatendo as propostas de criminalização da homofobia e de união civil de pessoas de mesmo sexo, atacando o "kit gay" e defendendo a "cura gay", os estatutos do nascituro e da família e o programa Escola sem Partido. Resultado: no segundo turno da eleição presidencial, $69 \%$ dos votos válidos dos eleitores evangélicos foram para Jair Bolsonaro, contra 31\% para Fernando Haddad, segundo pesquisa 
do Datafolha realizada em 25 de outubro. Entre os católicos, a diferença a favor do candidato do PSL foi mínima, de apenas dois pontos (51\% contra 49\%). Haddad perdeu também entre seguidores espíritas e de outras religiões, nos quais obteve $45 \%$ e $32 \%$ dos votos válidos, respectivamente. Superou Bolsonaro apenas entre adeptos das religiões afro-brasileiras (70\%), sem religião (55\%), ateus e agnósticos (64\%).

Baseado na pesquisa do Datafolha, o estatístico José Eustáquio Diniz Alves (2018) estima que os evangélicos deram 11 milhões de votos válidos a mais para Bolsonaro, cifra superior à diferença final de votos entre ele e Haddad registrada nas urnas, que foi de 10,76 milhões. Por isso, pontificou: "Bolsonaro foi eleito, fundamentalmente, com o voto evangélico, quando se considera a variável religião" (Alves 2018:n.p.).

Como explicar tamanha clivagem eleitoral entre os evangélicos em prejuízo do candidato petista? As repercussões negativas das manifestações de rua, da crise econômica e das acusações de corrupção sobre o Governo Dilma, o PT e seus aliados espraiaram-se por vastos setores do eleitorado brasileiro e em todos os grupos religiosos. Não explicam as gritantes diferenças entre o voto de católicos e o de evangélicos no segundo turno. $\mathrm{O}$ acirramento dos conflitos entre líderes e parlamentares evangélicos e deputados, dirigentes e governantes petistas teve peso determinante para a demonização do candidato petista e para o apoio eleitoral maciço que esses religiosos deram a seu adversário. $\mathrm{O}$ apoio eleitoral de pastores e líderes denominacionais, por meio de uma retórica corporativa, costuma ter eficácia para eleger candidatos evangélicos a cargos proporcionais, mas, com poucas exceções (casos de Collor em 1989, Crivella em 2016), ao menos enquanto são minoritários, tem pouco impacto para os cargos executivos. Em contraste, o maciço apoio pastoral a Bolsonaro pesou na decisão eleitoral de boa parte do eleitorado evangélico em 2018.

Católico e, ao mesmo tempo, batizado, em 2016, nas águas do Rio Jordão pelo pastor Everaldo, líder do PSC, Bolsonaro conseguiu capturar o apoio evangélico, assumindo bandeiras e valores cristãos. No segundo turno, pastores e dirigentes evangélicos apostaram que ele poderia derrotar o inimigo petista e os perigos e riscos que lhe atribuíam. É elucidativo o teor dos apoios dados por líderes evangélicos ao capitão: 1) Silas Malafaia prega: ele é "o único que defende diretamente a ideologia da direita", "é a favor dos valores de família", e em contraste: "Um verdadeiro cristão não vota em Haddad. Haddad é comunista disfarçado. A vice é comunista declarada. [...] O PT é a favor do aborto, o cristão verdadeiro é contra; o PT é a favor do casamento gay, o verdadeiro cristão é contra; o PT é a favor de erotizar crianças em escolas, o verdadeiro cristão é contra. Haddad é o autor do kit gay"10; 2) Robson Rodovalho, da Sara Nossa Terra, afirma: Bolsonaro é o "único que empunhou a bandeira da vida, da família, da igreja, da livre economia, da escola sem partido e contra a ideologia de gênero"11; 3) Pastor Rina, da Bola de Neve, sublinha que "é a primeira vez em todos esses anos que a gente tem um candidato de direita de verdade", "prófamília", "pró-deus", "pró-valores", "pelos nossos princípios", "favorável à igreja de Jesus"12 (Mariano e Gerardi 2019:69-70). 
Os apoios pastorais ao candidato do PSL associaram-no, diretamente, à defesa da família, da vida, da igreja, da moralidade cristã tradicional, do Escola sem Partido, pautas que advogam, ardorosamente, nos templos, nas mídias e nos parlamentos. Defenderam-no como o candidato "de direita de verdade", a favor da "livre economia" e contra a "ideologia de gênero". Ao mesmo tempo, atacaram o petista, acusando-o de comunista, de combater os valores cristãos, de "erotizar crianças em escolas" por meio do "kit gay" e de apoiar reivindicações feministas e LGBTs. Ao "verdadeiro cristão", prescreveram o voto no capitão e a rejeição ao petista.

Por certo, a decisão de Haddad de aproveitar o dia de Nossa Senhora Aparecida, em 12 de outubro, para identificar o adversário com "o casamento do neoliberalismo desalmado" e o "fundamentalismo charlatão do Edir Macedo" contribuiu para acirrar a mobilização eleitoral e midiática da Igreja Universal contra sua candidatura, além de municiar e reforçar o antipetismo entre os evangélicos ${ }^{13}$.

Em seu discurso de posse, Bolsonaro mostrou-se atento às pautas evangélicas, comprometendo-se a "valorizar a família, respeitar as religiões e nossa tradição judaico-cristã, combater a ideologia de gênero, conservando nossos valores" ${ }^{14}$.Em seguida, nomeou auxiliares afinados ideologicamente com esse discurso para os ministérios da Casa Civil, das Relações Exteriores, da Educação, da Mulher, Família e Direitos Humanos. Nos sete primeiros meses de mandato, participou de eventos com pastores e multidões de fiéis (Marcha para Jesus, entre outros), realizou dezenas de encontros com líderes denominacionais e integrantes da bancada evangélica, ampliou o financiamento federal a comunidades terapêuticas controladas por religiosos e conseguiu assegurar forte apoio ao governo nesse segmento religioso.

A sinergia entre a cúpula do governo de extrema direita e líderes e parlamentares evangélicos favorece a consolidação de uma direita cristã no Brasil que se assume como tal. Aos poucos, inclusive, começa a extrapolar o escopo de seu ativismo conservador centrado nos costumes, passando a aderir a ideário e políticas liberais na economia, apesar de sua base social majoritariamente de baixa renda.

\section{O dossiê}

Quatro artigos do dossiê investigam a inserção e os posicionamentos da Igreja Católica, suas instituições e representantes em disputas por direitos. O de Guilherme Borges, "Episcopado católico versus 3ํㅡㄹ Programa Nacional de Direitos Humanos: Uma análise dos atuais discursos eclesiásticos sobre sexo e reprodução", aborda os discursos episcopais em oposição a propostas do 3o Programa Nacional de Direitos Humanos (PNDH-3). Procura demonstrar que a autoridade pleiteada pelos bispos para se opor ao PNDH-3 não se remete à vocação divina da Igreja, que atravessaria milênios, mas à vocação democrática do catolicismo. Para tanto, o "catolicismo conservador renovado" recorre ao uso de repertórios seculares, como os do direito constitucional e do jusnaturalismo, a fim de legitimar seus posicionamentos e 
convicções contra as propostas de descriminalização do aborto, retirada de símbolos religiosos de edificações da União.

O artigo de Naara Luna e Laryssa Owsiany, "Aborto e luta por Direitos Humanos na ALERJ: Religiosos e feministas em disputa", converge na identificação de um ativismo religioso conservador contra os direitos sexuais e reprodutivos. Ao analisar discursos e projetos de lei sobre aborto na Assembleia Legislativa do Estado do Rio de Janeiro, constata seu enquadramento pelo posicionamento antiaborto liderado por religiosos, em sua maioria católicos e, em menor número, evangélicos. Apesar de publicizarem suas identidades e pertenças religiosas, eles não procuram se valer de um repertório de cunho religioso no exercício de sua atuação parlamentar. Em vez disso, instrumentalizam estratégias e discursos seculares para impedir a implementação dos direitos sexuais e reprodutivos, especialmente do aborto.

Tratando de outra frente de atuação do conservadorismo católico, o artigo de Renan Willian dos Santos, "Direitos da natureza e deveres religiosos: tensões entre a ecologia católica e movimentos ambientalistas seculares", examina o teor dos documentos emitidos pelo Vaticano sobre a questão ambiental. Podendo ser vista como uma faceta de seu "secularismo estratégico", a retórica ambiental católica compreende a crise ecológica como um problema moral. Como tal, a vincula ao desrespeito ao corpo humano e à natureza, os quais considera dons e criações de Deus. Dessa forma, seu ativismo ecológico opõe-se, simultaneamente, à destruição ambiental e ao aborto, à eutanásia e à reprodução assistida, fenômenos que, pontifica, afrontam os desígnios divinos.

Em "Para que todos tenham vida, e vida em abundância': a atividade missionária católica em defesa dos direitos das comunidades negras e quilombolas", Sabrina Soares D'Almeida observa o ativismo de entidades e missionárias católicas em defesa dos direitos territoriais de comunidades quilombolas no Vale da Ribeira/SP. A autora identifica que a defesa pública dos direitos desses grupos se vale do arcabouço jurídico para apontar sua violação e conferir legitimidade às suas reivindicações. Indica, pois, que o uso católico de termos e elementos seculares não se verifica exclusivamente na oposição às demandas de gênero e sexualidade, mas também, por exemplo, na defesa de direitos territoriais de comunidades marginalizadas. Observase o mesmo contraponto na luta em defesa dos direitos de outras minorias, tal como efetuada pelo Conselho Indigenista Missionário, pela Comissão Pastoral da Terra e pela Pastoral Carcerária.

O artigo de Paulo Gracino Junior, Janine Targino e Gabriel Silva Rezende, "Religiões públicas e demandas por reconhecimento: reflexões a partir dos dados da pesquisa com jovens participantes de movimentos religiosos de massa na cidade do Rio de Janeiro", analisa, com base em surveys, o perfil dos jovens presentes na Jornada Mundial da Juventude, na Marcha para Jesus e na Caminhada por Liberdades Religiosas, suas posições sobre temas como união civil de pessoas de mesmo sexo, direitos reprodutivos, igualdade de gênero, diversidade religiosa, comparando as posições desses 
jovens religiosos sobre essas questões. Ressalta que os evangélicos (majoritariamente pentecostais e assembleianos), com renda e escolaridade mais baixas, demonstraram menor tolerância à diversidade religiosa, maior desconfiança em relação às instituições públicas (governo federal e política), maior confiança nas instituições religiosas e maior reprovação da união de pessoas do mesmo sexo, da interrupção da gravidez, da eutanásia, do divórcio e da adoção de crianças por casais de pessoas do mesmo sexo.

Três artigos abordam diferentes fenômenos do ativismo político evangélico. O de Gustavo de Castro Patrício de Alencar, "Grupos protestantes e engajamento social: uma análise dos discursos e ações de coletivos evangélicos progressistas", examina o ativismo político da Frente de Evangélicos pelo Estado de Direito e do pastor batista Henrique Vieira em defesa dos Direitos Humanos, da justiça social e da democracia. Inspirados pela Teologia da Missão Integral e pela Teologia da Libertação, respectivamente, esses atores disputam a identidade evangélica e o significado de ser cristão, apoiando-se, para tal, em referências bíblicas e cristãs. Minoritários e frágeis institucionalmente, procuram, a fim de defender e hegemonizar suas causas em nome dos evangélicos, conquistar autoridade, visibilidade pública e legitimidade religiosa tanto na sociedade quanto no campo evangélico. Tarefas das mais árduas num meio religioso dominado pelo conservadorismo moral, teológico e político.

Claudia Swatowiski e Luciano Barbosa, em "Evangélicos em movimento por moradia: o caso da 'Ocupação do Glória' em Uberlândia”, Minas Gerais, examinam o papel exercido por pentecostais, em articulação com o Movimento dos Sem Teto do Brasil (MSTB), na organização de um movimento de luta por moradia. Engajados nessa luta, pastores e crentes pentecostais atuaram de diferentes formas, por meio da prestação de assistência social aos moradores do terreno e da mobilização de protestos. Efetuaram, além disso, uma ressignificação religiosa da "ocupação", tratando-a, concomitantemente, como direito à moradia (tendo por referência um direito básico de cidadania) e como "graça ou bênção divina". A posse da terra e a conquista da moradia, em seu discurso, podem ser alcançadas por meio da luta política e, também, da batalha espiritual, das mediações de orações e cultos e, por fim, da espera resignada da soberana providência divina.

Alexandre Oviedo Gonçalves, em "Religião, política e direitos sexuais: controvérsias públicas em torno da cura gay", analisa a disputa entre parlamentares evangélicos e psicólogos cristãos e seus adversários políticos, acadêmicos e ativistas LGBTs envolvendo a Resolução 1 do Conselho Federal de Psicologia, que proíbe os profissionais da área de tratar e reorientar a homossexualidade e de considerá-la uma doença. Investiga como esses atores, a partir da pluralidade de suas posições sociais, especialidades e fontes normativas (morais, religiosas, biomédicas, jurídicas, dos Direitos Humanos), propõem divergentes regimes de regulação da sexualidade. Diante da incontornável legitimidade dos Direitos Humanos (que trata os LGBTs como sujeitos de direito) e do aparato constitucional, deputados e psicólogos cristãos conservadores, em suas pelejas parlamentares e judiciais em defesa do direito dos psicólogos de 
tratarem a homossexualidade, recorrem cada vez mais à gramática jurídica e a justificativas e argumentos científicos para advogar e tentar legitimar suas proposições de fundo moral e religioso.

Sandra Lúcia Goulart, em "A política das religiões ayahuasqueiras brasileiras: droga, religião e direitos", analisa como esses grupos religiosos conseguiram dissociar das drogas a imagem pública da ayahuasca. A legitimação da sacralidade dessa bebida e de seu uso ritual, observa, foi decisiva para o próprio reconhecimento estatal dos grupos ayahuasqueiros como religião. Em consonância com outros estudos sobre o tema, mostra que o direito ao uso religioso da ayahuasca foi conquistado por meio de complexa interlocução de ativistas religiosos com pesquisadores acadêmicos e agentes e órgãos estatais responsáveis pelas políticas de drogas, que resultou na regulação pública do uso cerimonial dessa bebida e na legitimação das religiões ayahuasqueiras.

\section{Referências Bibliográficas}

BÉRAUD, Céline. (2013), "Les catholiques contre le genre. L'épisode des manuels de SVT". In: F. Rochefort; M. E. Sanna (dir.). Normes religieuses et genre: Mutations, résistances et reconfiguration (XIXe-XXIe siècle). Paris: Armand Colin/Recherches.

BÉRAUD, Céline; PORTIER, Philippe. (2015), Métamorphoses catholiques. Acteurs, enjeux et mobilisations depuis le mariage pour tous. Paris: Éditions de la Maison des sciences de l'homme.

CARNAC, Romain. (2013), "S’adapter pour mieux résister: la théologie de la sexualité de Jean-Paul II". In: F. Rochefort; M. E. Sanna (dir.). Normes religieuses et genre: Mutations, résistances et reconfiguration. Paris: Armand Colin/Recherches.

DALMOLIN, Aline. (2011), "Aborto, Igreja Católica e movimento feminista nos anos oitenta: uma cruzada de valores". X Seminário de Estudos Históricos. FEEVALE, Rio Grande do Sul.

DOBBELAERE, Karel; PEREZ-AGOTE, Alfonso. (2015), The intimate: Laws about life, death and the family in so-called catholic countries. Leuven: Leuven University Press.

GARBAGNOLI, Sara. (2014), "Le Vatican contre la dénaturalisation de l'ordre sexuel: structure et enjeux d'un discours institutionnel réactionnaire". Synergies, nํำ 10: 145-167.

GARBAGNOLI, Sara; PREARO,Massimo. (2017), La croisade anti-genre. Du Vatican aux manifs pour tous. Paris: Editions Textual.

GIUMBELLI, Emerson. (2008), "A presença do religioso no espaço público: Modalidades no Brasil". Religião $\mathcal{G}$ Sociedade, vol. 28, no 2: 80-101.

GONÇALVES, Rafael Bruno. (2016), O discurso religioso na política e a política no discurso religioso: uma análise da atuação da Frente Parlamentar Evangélica na Câmara dos Deputados (2003-2014). Rio de Janeiro: Tese de Doutorado em Sociologia, UERJ.

LUNA, Naara. (2013), "O direito à vida no contexto do aborto e da pesquisa com células-tronco embrionárias: disputas de agentes e valores religiosos em um Estado laico”. Religião $\mathfrak{E}$ Sociedade, vol. $33, n^{\circ} 1: 71-97$.

. (2018), "O julgamento no Supremo do aborto de anencéfalo - ADPF 54: uma etnografia da religião no espaço público". Horizontes Antropológicos, vol. 24, no 52: 165-197.

LICHTMAN, Allan. J. (2008), White protestant nation: The rise of the American conservative movement. New York: Grove Press.

MAINWARING, Scott. (1989), Igreja Católica e política no Brasil. 1916-1985. São Paulo: Brasiliense. 
MACHADO, Maria das Dores. (2017), "Pentecostais, sexualidade e família no Congresso Nacional". Horizontes Antropológicos, vol. 23, n 47: 351-380.

MARIANO, Ricardo; GERARDI, Dirceu André. (2019), "Eleições presidenciais na América Latina em 2018 e ativismo político de evangélicos conservadores". Revista USP, no 120: 61-76.

MICELI, Sergio. (1988), A elite eclesiástica brasileira (1890-1930). Rio de Janeiro: Bertrand Brasil.

MIGUEL, Luiz Felipe. (2016), “Da 'doutrinação marxista' à 'ideologia de gênero': Escola Sem Partido e as leis da mordaça no parlamento brasileiro". Direito e Práxis, vol. 7, no 15: 590-621.

MONTERO, Paula. (2006), "Religião, Pluralismo e esfera pública no Brasil". Novos Estudos - Cebrap, no 74: 47-65.

MONTERO, Paula; SILVA, Aramis; SALES, Lílian. (2018), "Fazer Religião em Público: encenações religiosas e influência pública". Horizontes Antropológicos, vol. 24, nº 52: 131-164.

OLIVEIRA, Luciano. (2018), "Mobilização e a contramobilização em torno do aborto: enfrentamentos entre feministas e representantes do Vaticano na Conferência do Cairo de 1994". Pensata, vol. 7, no 1: 59-74.

PIERUCCI, Antônio Flávio. (1996), "Representantes de Deus em Brasília: a bancada evangélica na Constituinte”. In: A. F. Pierucci; R. Prandi. A realidade social das religiões no Brasil. Religião, sociedade e política. São Paulo: Hucitec.

PONTIFÍCIO CONSELHO PARA A FAMÍLIA. (2003), Lexicon: termos ambíguos e discutidos sobre família, vida e questões éticas. Brasília: EdiçõesCNBB.

PORTIER, Philippe. (2012), Droit, éthique et religion. De l'âge théologique à l'âge bioéthique. Paris: Bruyant.

REZENDE, Patricia Jimenez. (2016), Movimentos sociais e contramovimentos: mobilizações antiaborto no Brasil contemporâneo. Guarulhos: Dissertação de Mestrado, UNIFESP.

ROCHA, Maria. (2005). "Discussões políticas e decisões no parlamento". In: M. Ávila; V. Ferreira; A. Portella (org.). Novas legalidades e democratização da vida social: família, sexualidade e aborto. Rio de Janeiro: Garamond.

ROSADO-NUNES, Maria José. (2008), "Direito, cidadania das mulheres e religião". Tempo social, vol. 20, no 2: 67-81.

SALES, Lilian. (2014), "A controvérsia em torno da liberação de pesquisas com células-tronco embrionárias no Brasil: posições e argumentos dos representantes da Igreja Católica". Revista de Antropologia, vol. 57, no 1: 179-213.

. (2015), "Em defesa da vida humana: moralidades em disputa em duas audiências públicas do STF”. Religião Eु Sociedade, vol. 35, nํ2: 143-164.

STEIL, Carlos Alberto; TONIOL, Rodrigo. (2012), "A trajetória dos Direitos Humanos na Igreja Católica no Brasil: do discurso político ao discurso moral”. In: P. R. de Oliveira; G. de Mori (org.). Mobilidade religiosa: linguagens, juventude, política. São Paulo: Paulinas.

TURINA, Isacco. (2012), "Le Magistere post-conciliare face au Biopouvoir”. In: C. Béraud; F. Gugelot; I. Saint Martin (dir.). Catholicisme en tension. Paris: Éd. de l'EHESS.

VAGGIONE, Juan. (2017), "La Iglesia Católica frente a la política sexual”. Cadernos Pagu, no 50: não paginado.

VITAL DA CUNHA, Christina; LOPES, Paulo Victor Leite. (2013), Religião e política. Uma análise da atuação de parlamentares evangélicos sobre direitos das mulheres e de LGBTs no Brasil. Rio de Janeiro: Heinrich Böll Stiftung; ISER.

VITAL DA CUNHA, Christina; LOPES, Paulo Victor Leite; LUI, Janayna. (2017), Religião e política: Medos sociais, extremismo religioso e eleições 2014. Rio de Janeiro: Gráfica Stamppa.

WOHNRATH, Vinícius Parolin. (2017), Constituindo a Nova República: agentes católicos na Assembleia Nacional 1987-1988. Campinas: Tese de Doutorado em Educação, Unicamp.

\section{Jornais consultados}

BALLOUSSIER, Anna Virginia. (2018), "Justiça manda que Haddad apague vídeo envolvendo 
Edir Macedo". Valor Econômico, Política, 3 nov. 2018. Disponível em: https:/www.valor.com.br/ politica/5966411/justica-manda-que-haddad-apague-video-envolvendo-edir-macedo. Acesso em: 05/11/2018.

ÉBOLI, Evandro. (2015), "Autor do Estatuto da Família diz que gays não querem direitos, mas 'privilégios'. O Globo, 13 fev. 2015. Disponível em: https://oglobo.globo.com/brasil/autor-doestatuto-da-familia-diz-que-gays-nao-querem-direitos-mas-privilegios-15328924\#ixzz5Aie5KpRR. Acesso em: 02/2016.

FRAZÃO, Felipe. (2018), "Bolsonaro recebe apoio de líderes evangélicos". Estadão, Política, 1o out. 2018. Disponível em: https://politica.estadao.com.br/noticias/eleicoes,bolsonaro-recebe-apoio-delideres-evangelicos, 70002527014. Acesso em: 05/11/2018.

O GLOBO. (2018), "Influenciador nas redes sociais, Silas Malafaia vai apoiar Bolsonaro com uso de canhão digital”. O Globo, 18 mar. 2018.

\section{Sites consultados}

ALVES, José Eustáquio Diniz. (2018), “O voto evangélico garantiu a eleição de Jair Bolsonaro". EcoDebate, 31 out. 2018. Disponível em:https://www.ecodebate.com.br/2018/10/31/o-votoevangelico-garantiu-a-eleicao-de-jair-bolsonaro-artigo-de-jose-eustaquio-diniz-alves/. Acesso em: 10/03/2019.

CORRÊA, Sônia; PATERNOTTE, David; KUHAR, Roman. (2018), "Europa, América Latina y la globalización de las campañas contra el género”. openDemocracy, 11 jun. 2018. Disponível em: https:/www.opendemocracy.net/democraciaabierta/sonia-correa-david-paternotte-roman-kuhar/ europa-am-rica-latina-y-la-globalizaci-n.

MACHADO, Leandro; FRANCO, Luiza. (2018), "Eleições 2018: os valores e 'boatos' que conduzem evangélicos a Bolsonaro”. BBC News Brasil, 23 out. 2018. Disponível em: https://www.bbc.com/ portuguese/brasil-45829796. Acesso em: 08/11/2018.

UOL. (2019), "Bolsonaro fala em combater ideologia de gênero; veja íntegra do discurso". UOL Notícias, 1 jan. 2019. Disponível em: https://noticias.uol.com.br/politica/ultimas-noticias/2019/01/01/ bolsonaro-fala-em-combater-ideologia-de-genero-veja-integra-do-discurso.htm?cmpid. Acesso em: 03/01/2019.

\section{Vídeos consultados}

\#ORIGINALCHURCHMOVEMENT \#RESTARTMOVEMENT. (2018), "Ouça o que o Apóstolo Rina - Bola de Neve - Falou sobre o Bolsonaro". Disponível em: https://www.youtube.com/ watch? $\mathrm{v}=\mathrm{ngcO}$ 7-kr4U\&t=728s. Acesso em: 08/11/2018.

SILAS MALAFAIA OFICIAL. (2018), Pastor Silas Malafaia comenta: Por que um verdadeiro cristão não vota em Haddad?. Disponível em: https://www.youtube.com/watch?v=QskGBZmNGxQ\&t=31s. Acesso em: 15/10/2018.

\section{Notas}

1 Esse foi um movimento de alcance internacional, muito forte na América Latina. Os documentos produzidos nas conferências do Conselho Episcopal Latino-Americano (CELAM), realizadas em Medellin (1968) e em Puebla (1979), balizaram e legitimaram as ações católicas em defesa dos Direitos Humanos (Steil e Toniol 2012; Mainwaring 1989).

2 A ênfase nos Direitos Humanos enquanto direitos sociais estava em consonância com as concepções da Teologia da Libertação, como a "opção preferencial pelos pobres", e com o objetivo de se "colocar a temática dos Direitos Humanos em termos da dignidade dos oprimidos” (Relatório final do II Encontro dos Direitos Humanos). 
3 Entre as Campanhas da Fraternidade, podem-se citar: Saúde e Fraternidade, com o lema "Saúde para Todos", em defesa do direito à saúde pública, que se universalizou apenas na Carta Constitucional de 1988; "Educação e Fraternidade", com o lema "A verdade vos libertará", advogando a universalização do direito à Educação; "Fraternidade e a Terra", com o lema "Terra de Deus, terra de irmãos", em prol do direito à terra e da reforma agrária (1986); Fraternidade e o Menor, com o lema "Quem acolhe o menor, a mim acolhe" (1987), em defesa dos direitos de crianças e adolescentes; A fraternidade e o Negro, com o lema "Ouvi o clamor desse povo", sobre os direitos dos negros.

4 Cabe fazer um parêntese para frisar que, desde os anos 1980, os Direitos Humanos se tornaram alvo de críticas e acusações de apresentadores de programas policiais de rádio e TV e de candidatos e parlamentares que os associaram a restrições ao trabalho policial e à proteção e impunidade de "bandidos". O lema "bandido bom é bandido morto", por sinal, tem o apoio de 57\% dos brasileiros, conforme pesquisa do Datafolha de 2016, encomendada pelo Fórum Brasileiro de Segurança Pública. Concepções que são compartilhadas atualmente por parcela expressiva dos brasileiros e advogadas por "bancadas da bala" na Câmara Federal e em assembleias legislativas.

5 Os principais movimentos antiaborto no Brasil, como o Movimento para a Cidadania: Brasil sem aborto e a Associação Nacional Pró-vida e Família, são integrados por instituições católicas e espíritas. O primeiro movimento tem entre seus membros a Pastoral da Família (órgão da CNBB) e a Federação Espírita Brasileira (FEB). A Associação Nacional Pró-vida e Família está vinculada à CNBB. Patricia Rezende (2016) classifica o movimento Nacional Brasil Sem Aborto como um contramovimento, formado em reação aos movimentos feministas e de mulheres e à proposição de descriminalização do aborto.

6 O Instituto Universitário Campo Biomédico, de Roma, e o Instituto de Bioética da Universidade de Navarra tornaram-se referência na formulação do discurso acadêmico católico sobre bioética, reprodução e sexualidade.

7 Disponível em: https://oglobo.globo.com/brasil/autor-do-estatuto-da-familia-diz-que-gays-nao-querem-direitosmas-privilegios-15328924\#ixzz5Aie5KpRR. Acesso em: 02/2016.

8 O Globo, 18/03/2018. "Influenciador nas redes sociais, Silas Malafaia vai apoiar Bolsonaro com uso de canhão digital".

9 Disponível em: https://www.bbc.com/portuguese/brasil-45829796. Acesso em: 08/11/2018.

10 Disponível em: https://www.youtube.com/watch?v=QskGBZmNGxQ\&t=31s. Acesso em: 15/10/2018.

11 Disponível em: https:/politica.estadao.com.br/noticias/eleicoes,bolsonaro-recebe-apoio-de-lideres-evangelicos,70002527014. Acesso em: 05/11/2018.

12 Disponível em: https://www.youtube.com/watch?v=ngcOz7-kr4U\&t=728s. Acesso em: 08/11/2018.

13 Disponível em: https://www.valor.com.br/politica/5966411/justica-manda-que-haddad-apague-video-envolvendo-edir-macedo. Acesso em: 05/11/2018.

14 Disponível em: https://noticias.uol.com.br/politica/ultimas-noticias/2019/01/01/bolsonaro-fala-em-combater-ideologia-de-genero-veja-integra-do-discurso.htm?cmpid. Acesso em: 03/01/2019.

Este trabalho está licenciado com uma Licença Creative Commons - Atribuição Não-Comercial 4.0 Internacional 